\title{
DAYA TERIMA KONSUMEN DAN SIFAT FISIK ROTI SOFT ROLL SUBSTITUSI TEPUNG HANJELI (C. Lacryma-jobi L.)
}

\author{
[The Consumer's Acceptance and Physical Characteristics of Soft Roll with Job's Tear Flour (C.Lacryma-jobi L.) \\ Substitution] \\ Irwan ${ }^{1^{*}}$, Mutiara Dahlia ${ }^{1}$, Rusilanti $^{1}$ \\ ${ }^{1}$ Program Studi Pendidikan Tata Boga, Fakultas Teknik, Universitas Negeri Jakarta \\ *Email: irwanstrd@gmail.com (Telp: +6285921310281)
}

Diterima tanggal 24 Maret 2021

Disetujui tanggal 15 April 2021

\begin{abstract}
The aim of this research was to analyze the effect of Job's tear flour substitution in bread making on the consumer's acceptance based on external (volume, crust's color, form's symmetry, bake's evenness, crust characteristic), internal (grain, crumb's color, aroma, flavor, texture), and physical (volume, growth power ratio) characteristics. This research used an experimental method. The sample of this research was soft roll with Job's tear substitution with a percentage of $10 \%$, $20 \%$, and $30 \%$. The data collection technique used was a preference test by 25 untrained panelists. The results of the preference test show that soft roll bread substituted with 10\% flour was the most preferred product in the internal aspect with a value range of 4.00 to 4.24 and soft roll bread substituted for $20 \%$ Job's tear flour was the most preferred product in almost all external aspects with vulnerable values from 4.24 to 4.40 . Based on the Friedman test results with a significant difference $=0.05$, there was an effect of flour substitution on aspects of volume, crust's color, crust characteristic, grain, aroma, flavor, and texture on the soft roll. Tuckey test results show that soft roll bread substituted with $10 \%$ Job's tear flour was the most preferred and was recommended to be developed. The physical assessment shows that soft roll bread substituted with $10 \%$ Job's tear flour had the largest volume and expansion ratio compared to other samples.
\end{abstract}

Keywords: soft roll, Job's tear flour, consumer's acceptance

\section{ABSTRAK}

Penelitian ini dilakukan untuk mengetahui pengaruh substitusi tepung hanjeli dalam pembuatan roti soft roll terhadap daya terima konsumen pada aspek eksternal (volume, warna kulit roti, bentuk, keseragaman pemanggangan, karakter kulit roti) aspek internal (pori-pori roti, warna crumb, aroma, rasa, tekstur) dan sifat fisik roti (volume roti, rasio pengembangan). Penelitian ini menggunakan metode ekperimen. Sampel dalam penelitian ini adalah roti soft roll substitusi tepung hanjeli dengan persentase $10 \%, 20 \%$, dan $30 \%$. Teknik pengumpulan data yang digunakan adalah tes kesukaan oleh 25 panelis tidak terlatih. Hasil tes kesukaan menunjukan roti soft roll substitusi tepung hanjeli $10 \%$ merupakan produk yang paling disukai pada aspek internal dengan rentan nilai 4,00 hingga 4,24 dan roti soft roll substitusi tepung hanjeli $20 \%$ merupakan produk yang paling disukai pada hampir semua aspek eksternal dengan rentan nilai 4,24 hingga 4,40. Berdasarkan hasil uji Friedman dengan perbedaan signifikan $\alpha=0,05$ menyatakan terdapat pengaruh substitusi tepung pada aspek volume, warna kulit roti, karakter kulit roti, pori-pori roti, aroma, rasa hanjeli, dan tekstur. Hasil uji Tuckey menunjukan bahwa roti soft roll substitusi tepung hanjeli $10 \%$ adalah yang disukai konsumen, sehingga direkomendasikan untuk dikembangkan. Penilaian fisik menunjukkan roti soft roll substitusi tepung hanjeli $10 \%$ memiliki volume dan rasio pengembangan terbesar dibandingkan sampel lainnya.

Kata kunci: roti soft roll, tepung hanjeli, daya terima konsumen 


\section{PENDAHULUAN}

Konsumsi tepung terigu di Indonesia terus mengalami peningkatan seiring dengan meningkatnya kebutuhan konsumsi komoditas pangan tepung terigu, seperti: biskuit, mie instan, pasta, produk bakery, dan lainnya (APTINDO, 2016). Pada produk bakery seperti roti, penggunaan tepung terigu merupakan salah satu kunci yang paling penting dalam pembuatannya. Tepung terigu mengandung protein dalam bentuk gluten yang dapat membuat roti mengembang, hal ini disebabkan karena kandungan gluten mampu menahan gas hasil fermentasi (Koswara, 2009).

Namun tepung terigu diperoleh dengan cara impor untuk memenuhi kebutuhan konsumsi di Indonesia. Ketergantungan pada produk pangan yang di impor, yang semakin meningkat volume maupun nilainya, dapat mengancam ketahanan pangan dalam negeri (Supadi, 2009). Salah satu upaya untuk menghindari ancaman terhadap ketahanan pangan dalam negeri, yaitu melalui diversifikasi pangan (Sumaryanto, 2009). Diversifikasi pangan merupakan upaya meningkatkan ketersediaan pangan yang beragam dan berbasis potensi sumber daya lokal, yang tidak bergantung kepada satu jenis bahan saja (Litbang, 2013). Sebagai langkah mengurangi pemakaian jumlah tepung terigu maka perlu dilakukan diversifikasi pangan, sehingga dapat mendukung ketahanan pangan nasional dan dapat mengurangi ketergantungan terhadap tepung terigu. Salah satu sumber daya lokal yang potensial dan memiliki prospek yang baik untuk dikembangkan adalah hanjeli (Coix LacrymaJobi L.).

Hanjeli memiliki kandungan karbohidrat yang tinggi, sehingga cocok diolah menjadi tepung. Kekuatan tepung untuk mengembang (sweilling power) pada tepung hanjeli sebesar $11(\mathrm{~g} / \mathrm{g}$ ) mendekati tepung terigu yang sebesar 13 (g/g) (Kutschera dan Krasaekoopt, 2012). Selain itu, kandungan pada tepung hanjeli secara umum sudah memenuhi persyaratan mutu dari tepung terigu. Kandungan lemak dan kalsium pada tepung hanjeli cukup tinggi, yakni 4,6 gram lemak dan 54 mg kalsium per 100 gram tepung hanjeli (Kurniasih, 2016). Lemak dalam pembuatan roti mampu membuat tekstur roti menjadi lembut dan kalsium membuat gluten menjadi lebih kuat, sehingga hasil pengembangan pada roti lebih optimal.

Salah satu jenis roti yang memerlukan hasil pengembangan volume yang baik dan memiliki tekstur yang lembut adalah roti soft roll, roti lembut yang tidak boleh memiliki kerak pada permukaan bawahnya. Roti soft roll varian single dinner roll dipilih dalam penelitian ini dengan substitusi tepung hanjeli dapat memiliki bentuk yang sederhana dan mudah dibuat sehingga dapat meminimalisirkan kemungkinan over-proof pada proses pembentukan roti soft roll.

Pembuatan roti soft roll substitusi tepung hanjeli merupakan salah satu langkah untuk mengurangi penggunaan tepung terigu dan mengenalkan pemanfaatan lain dari hanjeli yang diharapkan dapat diterima oleh konsumen. 


\section{BAHAN DAN METODE}

\section{Bahan}

Bahan-bahan yang digunakan dalam pembuatan sampel roti tawar soft roll adalah tepung terigu protein tinggi, tepung hanjeli, ragi instan, garam, gula pasir, susu bubuk, bread improver, telur, air es, dan lemak. Bahan yang digunakan untuk membuat tepung hanjeli adalah biji hanjeli dan larutan ragi tapai (Saccharomyces cerevisae) $1 \%$.

\section{Tahapan Penelitian}

\section{Pembuatan Tepung Hanjeli (Syahputri dan Wardani ,2015)}

Penelitian ini meliputi proses pembuatan tepung hanjeli, yaitu biji hanjeli dicuci bersih, direndam dalam larutan ragi tapai 1\% selama 72 jam, pengeringan, penggilingan, dan dilanjutkan dengan pengayakan untuk mendapatkan tepung hanjeli yang halus dengan ayakan ukuran 120 mesh.

\section{Pembuatan Roti (Mudjajanto dan Yuliati, 2013)}

Pembuatan roti soft roll dengan substitusi tepung hanjeli sesuai dengan resep standar yang digunakan. Bahan berupa tepung terigu protein tinggi, tepung hanjeli, ragi instan, gula pasir, susu bubuk, dan bread improver diaduk menggunakan mixer dengan kecepatan rendah selama 2 menit. Kemudian ditambahkan telur dan air es, diaduk hingga bahan tercampur rata dan tidak lengket di wadah dengan kecepatan rendah. Setelah itu ditambahkan lemak dan garam, diaduk kembali dengan kecepatan sedang hingga kalis. Adonan diistirahatkan selama 10 menit kemudian dipotong-timbang 30 gram per potongnya. Adonan yang telah dipotong-timbang diistirahatkan selama 10 menit, lalu dilakukan pembuangan gas dan pembentukan soft roll. Setelah itu difermentasikan selama 50 menit dan dipanggang selama 15 menit dengan suhu atas $180^{\circ} \mathrm{C}$ dan subu bawah $160^{\circ} \mathrm{C}$.

\section{Penilaian Organoleptik}

Penilaian organoleptik dilakukan terhadap sampel roti soft roll pada aspek eksternal (volume, warna kulit roti, bentuk, keseragaman pemanggangan, dan karakter kulit roti) dan aspek internal (pori-pori roti, warna crumb, aroma, rasa, dan tekstur). Pengujian dilakukan terhadap 25 panelis tidak terlatih. Skor penilaian diberikan berdasarkan tingkat kesukaan panelis dengan skala yang digunakan adalah 1= sangat tidak suka, 2= tidak suka, 3= agak suka, $4=$ suka, $5=$ sangat suka.

\section{Analisis Sifat Fisik}

Analisis sifat fisik dilakukan terhadap tepung hanjeli yang dibuat dengan mengukur densitas kamba (Khalil, 1999), densitas pemadatan (Khalil, 1999), dan daya serap air (Muchtadi et al, 2010). Analisis sifat fisik terhadap roti soft roll yang dibuat meliputi pengukuran volume roti dengan metode biji-bijian dan analisa rasio pengembangan (Surono et al, 2017). 


\section{Rancangan Penelitian}

Rancangan penelitian yang digunakan dalam penelitian ini adalah membuat roti soft roll substitusi tepung hanjeli dengan tiga persentase, yaitu P1 (90\% tepung terigu : 10\% tepung hanjeli), P2 (80\% tepung terigu : 20\% tepung hanjeli), dan P3 (70\% tepung terigu : 30\% tepung hanjeli).

\section{Analisis Data}

Data yang diperoleh dari hasil penilaian orgnanoleptik terhadap roti soft roll substitusi tepung hanjeli akan dianalisis dengan menggunakan tes friedman, apabila terdapat pengaruh akan dilanjutkan dengan uji tuckey. Uji analisis dilakukan pada taraf kepercayaan $95 \%(\alpha=0,05)$.

\section{HASIL DAN PEMBAHASAN}

\section{Uji Organoleptik}

Pada penelitian ini penilaian roti soft roll sibstitusi tepung hanjeli dilakukan terhadap aspek eksternal yang meliputi: volume, warna kulit roti, bentuk, keseragaman pemanggangan, dan karakter kulit roti; dan aspek internal yang meliputi: pori-pori roti, warna crumb, aroma, rasa hanjeli, rasa manis, dan tekstur. Kode sampel 903 adalah untuk roti soft roll substitusi tepung hanjeli 30\% (P3), kode sampel 389 adalah untuk roti soft roll substitusi tepung hanjeli 20\% (P2), dan kode sampel 285 adalah untuk roti soft roll substitusi tepung hanjeli 10\% (P1).

Tabel 1 Penilaian Hasil Uji Daya Terima Aspek Volume

\begin{tabular}{|c|c|c|c|c|c|c|}
\hline \multirow{3}{*}{ Skala Penilaian } & \multicolumn{6}{|c|}{ Roti Soft Roll Substitusi Tepung Hanjeli } \\
\hline & \multicolumn{2}{|c|}{$30 \%$} & \multicolumn{2}{|c|}{$20 \%$} & \multicolumn{2}{|c|}{$10 \%$} \\
\hline & $\mathrm{n}$ & $\%$ & $\mathrm{n}$ & $\%$ & $\mathrm{n}$ & $\%$ \\
\hline Sangat Suka & 6 & 24 & 11 & 44 & 11 & 44 \\
\hline Suka & 9 & 36 & 13 & 52 & 9 & 36 \\
\hline Agak Suka & 10 & 40 & 1 & 4 & 5 & 20 \\
\hline Tidak Suka & 0 & 0 & 0 & 0 & 0 & 0 \\
\hline Sangat Tidak Suka & 0 & 0 & 0 & 0 & 0 & 0 \\
\hline Jumlah & 25 & 100 & 25 & 100 & 25 & 100 \\
\hline Mean & $3,84^{b} \pm 0,80$ & & $4,40^{\mathrm{a}} \pm 0,58$ & & $4,24^{\mathrm{ab}} \pm 0,78$ & \\
\hline Modus & 3 & & 4 & & 5 & \\
\hline
\end{tabular}

Rata-rata skor penilaian hasil uji daya terima aspek volume pada roti soft roll substitusi tepung hanjeli menunjukkan bahwa, roti soft roll dengan substitusi tepung hanjeli 30\% dengan skor 3,84 termasuk ke dalam kategori mendekati suka. Sedangkan roti soft roll dengan substitusi tepung hanjeli $20 \%$ dengan skor 4,40 dan 10\% dengan skor 4,24 termasuk dalam kategori suka. Setelah dilakukan uji Friedman nilai $\mathrm{x}$ hitung diperoleh sebesar 11,444 yang dapat diartikan terdapat perbedaan terhadap aspek volume pada sampel roti soft roll. Perbedan ini dapat disebabkan penggunaan tepung hanjeli pada pembuatan roti soft roll. Penggunaan tepung 
hanjeli dengan persentase yang semakin besar akan mengurangi kandungan gluten pada adonan roti, sehingga menurunkan kemampuan menahan gas dan daya kembang roti soft roll yang dihasilkan (Wijayanti, 2007). Selain itu,kekuatan tepung untuk mengembang (swelling power) pada tepung hanjeli tidak sebaik tepung terigu, karena semakin besar angka swelling power semakin baik tingkat pengembangannya (Kusumayanti et. al, 2014). Setelah melalui uji tukey, sampel 389 berbeda nyata dengan sampel 903.

Tabel 2. Penilaian Hasil Uji Daya Terima Aspek Warna Kulit Roti

\begin{tabular}{|c|c|c|c|c|c|c|}
\hline \multirow{3}{*}{ Skala Penilaian } & \multicolumn{6}{|c|}{ Roti Soft Roll Substitusi Tepung Hanjeli } \\
\hline & \multicolumn{2}{|c|}{$30 \%$} & \multicolumn{2}{|c|}{$20 \%$} & \multicolumn{2}{|c|}{$10 \%$} \\
\hline & $\mathrm{n}$ & $\%$ & $\mathrm{n}$ & $\%$ & $\mathrm{n}$ & $\%$ \\
\hline Sangat Suka & 3 & 12 & 12 & 48 & 7 & 28 \\
\hline Suka & 18 & 72 & 11 & 44 & 13 & 52 \\
\hline Agak Suka & 3 & 12 & 2 & 8 & 5 & 20 \\
\hline Tidak Suka & 1 & 4 & 0 & 0 & 0 & 0 \\
\hline Sangat Tidak Suka & 0 & 0 & 0 & 0 & 0 & 0 \\
\hline Jumlah & 25 & 100 & 25 & 100 & 25 & 100 \\
\hline Mean & $3,92^{b} \pm 0,64$ & & $4,40^{\mathrm{a}} \pm$ & & $\mathrm{ab} \pm$ & \\
\hline Modus & 4 & & 5 & & 4 & \\
\hline
\end{tabular}

Keterangan : Angka-angka yang diikuti oleh huruf yang berbeda pada baris yang sama berbeda nyata pada taraf signifikansi 0,05

Rata-rata skor penilaian hasil uji daya terima aspek warna kulit pada roti soft roll substitusi tepung hanjeli menunjukkan bahwa, roti soft roll substitusi tepung hanjeli 30\% dengan skor 3,92 termasuk ke dalam kategori mendekati suka. Sedangkan roti soft roll substitusi tepung hanjeli $20 \%$ dengan skor 4,40 dan $10 \%$ dengan skor 4,08 termasuk ke dalam kategori suka. Setelah dilakukan uji Friedman nilai x hitung diperoleh sebesar 6,862 yang dapat diartikan terdapat perbedaan terhadap aspek warna kulit roti pada sampel roti soft roll. Perbedaan ini dapat disebabkan karena reaksi mailard, yaitu proses pencokelatan yang terjadi karena reaksi antara karbohirat dan protein saat proses pemanasan yang menghasilkan warna cokelat (Rahmah et al, 2017). Kandungan karbohidrat pada tepung hanjeli tidak setinggi tepung terigu (Kurniasih, 2016), sehingga proses pencokelatan pada roti soft roll agak sedikit berkurang. Selain itu, warna tepung hanjeli yang dibuat lebih cerah dari pada tepung terigu. Semakin banyak persentase tepung hanjeli yang digunakan warna kulit roti yang dihasilkan berwarna lebih pucat. Dan faktor kestabilan suhu pada oven dapat juga mempengaruhi hasil warna kulit roti. Setelah melalui uji tukey, sampel 389 berbeda nyata dengan sampel 903.

Tabel 3. Penilaian Hasil Uji Daya Terima Aspek Bentuk

\begin{tabular}{lcccccc}
\hline & \multicolumn{7}{c}{ Roti Soft Roll Substitusi Tepung Hanjeli } \\
\cline { 2 - 7 } \multicolumn{1}{c}{ Skala Penilaian } & \multicolumn{2}{c}{$30 \%$} & \multicolumn{2}{c}{$20 \%$} & \multicolumn{1}{c}{$10 \%$} \\
\cline { 2 - 7 } & $\mathrm{n}$ & $\%$ & $\mathrm{n}$ & $\%$ & $\mathrm{n}$ & $\%$ \\
\hline Sangat Suka & 3 & 12 & 17 & 68 & 14 & 28 \\
Suka & 17 & 68 & 3 & 12 & 4 & 16 \\
Agak Suka & 4 & 16 & 0 & 0 & 0 & 0 \\
Tidak Suka & 1 & 4 & 0 & & \\
\end{tabular}




\begin{tabular}{lcccccc}
\hline Jumlah & 25 & 100 & 25 & 100 & 25 & 100 \\
\hline Mean & $3,88 \pm 0,67$ & & $4,08 \pm 0,57$ & & $4,12 \pm 0,67$ & \\
Modus & 4 & & 4 & 4 & \\
\hline
\end{tabular}

Rata-rata skor penilaian hasil uji daya terima aspek bentuk pada roti soft roll substitusi tepung hanjeli menunjukkan bahwa, roti soft roll substitusi tepung hanjeli 30\% dengan skor 3,88 termasuk ke dalam kategori mendekati suka. Sedangkan roti soft roll substitusi tepung hanjeli $20 \%$ dengan skor 4,08 dan $10 \%$ dengan skor 4,12 termasuk ke dalam kategori suka. Setelah dilakukan uji Friedman nilai x hitung diperoleh sebesar 4,098 yang dapat diartikan tidak terdapat pengaruh terhadap aspek bentuk pada sampel roti soft roll yang telah dibuat. Penggunaan tepung hanjeli sampai dengan $30 \%$ pada pembuatan roti soft roll masih dapat menghasilkan bentuk roti yang simetris dan menarik.

Tabel 4. Penilaian Hasil Uji Daya Terima Aspek Keseragaman Pemanggangan

\begin{tabular}{lcccccc}
\hline \multirow{2}{*}{ Skala Penilaian } & \multicolumn{5}{c}{ Roti Soft Roll Substitusi Tepung Hanjeli } \\
\cline { 2 - 7 } & \multicolumn{2}{c}{$30 \%$} & & $20 \%$ & & $10 \%$ \\
\cline { 2 - 7 } & $\mathrm{N}$ & $\%$ & $\mathrm{n}$ & $\%$ & $\mathrm{n}$ & $\%$ \\
\hline Sangat Suka & 3 & 12 & 10 & 40 & 8 & 32 \\
Suka & 17 & 68 & 11 & 44 & 11 & 44 \\
Agak Suka & 4 & 16 & 4 & 16 & 6 & 24 \\
Tidak Suka & 1 & 4 & 0 & 0 & 0 & 0 \\
Sangat Tidak Suka & 0 & 0 & 0 & 0 & 0 & 0 \\
\hline Jumlah & 25 & 100 & 25 & 100 & 25 & 100 \\
\hline Mean & $3,88 \pm 0,67$ & & $4,24 \pm 0,72$ & & $4,08 \pm 0,76$ & \\
Modus & 4 & & 4 & & 4 & \\
\hline
\end{tabular}

Rata-rata skor penilaian hasil uji daya terima aspek keseragaman pemanggangan pada roti soft roll substitusi tepung hanjeli menunjukkan bahwa, roti soft roll substitusi tepung hanjeli $30 \%$ dengan skor 3,88 termasuk ke dalam kategori mendekati suka. Sedangkan roti soft roll substitusi tepung hanjeli $20 \%$ dengan skor 4,24 dan 10\% dengan skor 4,08 termasuk ke dalam kategori suka. Setelah dilakukan uji Friedman nilai x hitung diperoleh sebesar 5,460 yang dapat diartikan tidak terdapat perbedaan terhadap aspek keseragaman pemanggangan pada sampel roti soft roll. Penggunaan tepung hanjeli sampai dengan 30\% pada pembuatan roti soft roll masih menghasilkan roti dengan hasil pemanggangan yang matang secara merata pada setiap sisi roti soft roll. 
Tabel 5. Penilaian Hasil Uji Daya Terima Aspek Karakter Kulit Roti

\begin{tabular}{lcccccc}
\hline \multirow{2}{*}{ Skala Penilaian } & \multicolumn{5}{c}{ Roti Soft Roll Substitusi Tepung Hanjeli } \\
\cline { 2 - 7 } & \multicolumn{2}{c}{$30 \%$} & $\mathrm{n}$ & $\%$ & $\mathrm{n}$ & $\%$ \\
\cline { 2 - 7 } & $\mathrm{N}$ & $\%$ & 9 & 36 & 9 & 36 \\
Sangat Suka & 5 & 20 & 16 & 64 & 14 & 56 \\
Suka & 16 & 64 & 0 & 0 & 2 & 8 \\
Agak Suka & 4 & 16 & 0 & 0 & 0 & 0 \\
Tidak Suka & 0 & 0 & 0 & 0 & 0 & 0 \\
Sangat Tidak Suka & 0 & 0 & 0 & 100 & 25 & 100 \\
\hline Jumlah & 25 & 100 & 25 & $4,28 \pm 0,61$ & \\
\hline Mean & $4,04 \pm 0,61$ & & $4,36 \pm 0,49$ & & 4 & \\
Modus & 4 & 4 & & & \\
\hline
\end{tabular}

Rata-rata skor penilaian hasil uji daya terima aspek karakter kulit roti pada roti soft roll substitusi tepung hanjeli menunjukkan bahwa, roti soft roll substitusi tepung hanjeli 30\% dengan skor 4,04; $20 \%$ dengan skor 4,36; dan $10 \%$ dengan skor 4,28 termasuk ke dalam kategori suka. Setelah dilakukan uji Friedman nilai $\mathrm{x}$ hitung diperoleh sebesar 5,895 yang dapat diartikan tidak terdapat perbedaan terhadap aspek karakter kulit roti pada sampel roti soft roll. Penggunaan tepung hanjeli sebagai bahan substitusi pada pembuatan sampel roti soft roll tidak memberikan pengaruh yang signifikan terhadap karakter kulit roti yang dihasilkan.

Tabel 6. Penilaian Hasil Uji Daya Terima Aspek Pori-Pori Roti

\begin{tabular}{|c|c|c|c|c|c|c|}
\hline \multirow{3}{*}{ Skala Penilaian } & \multicolumn{6}{|c|}{ Roti Soft Roll Substitusi Tepung Hanjeli } \\
\hline & \multicolumn{2}{|c|}{$30 \%$} & \multicolumn{2}{|c|}{$20 \%$} & \multicolumn{2}{|c|}{$10 \%$} \\
\hline & $n$ & $\%$ & $\mathrm{n}$ & $\%$ & $n$ & $\%$ \\
\hline Sangat Suka & 2 & 8 & 5 & 20 & 5 & 20 \\
\hline Suka & 17 & 68 & 18 & 72 & 20 & 80 \\
\hline Agak Suka & 6 & 24 & 2 & 8 & 0 & 0 \\
\hline Tidak Suka & 0 & 0 & 0 & 0 & 0 & 0 \\
\hline Sangat Tidak Suka & 0 & 0 & 0 & 0 & 0 & 0 \\
\hline Jumlah & 25 & 100 & 25 & 100 & 25 & 100 \\
\hline Mean & $3,84^{b} \pm 0,55$ & & $4,12^{a b} \pm 0,53$ & & $4,20^{\mathrm{a}} \pm 0$ & \\
\hline Modus & 4 & & 4 & & 4 & \\
\hline
\end{tabular}

Rata-rata skor penilaian hasil uji daya terima aspek pori-pori roti pada roti soft roll substitusi tepung hanjeli menunjukkan bahwa, roti soft roll substitusi tepung hanjeli $30 \%$ dengan skor 3,84 termasuk ke dalam kategori mendekati suka. Sedangkan roti soft roll substitusi tepung hanjeli $20 \%$ dengan skor 4,12 dan $10 \%$ dengan skor 4,20 termasuk ke dalam kategori suka. Setelah dilakukan uji Friedman nilai $\mathrm{x}$ hitung diperoleh sebesar 8,424 yang dapat diartikan terdapat perbedaan terhadap aspek pori-pori pada sampel roti soft roll. Poripori roti terbentuk pada saat proses fermentasi oleh gluten yang membentuk lapisan tipis yang menahan gas. Penggunaan tepung hanjeli yang semakin banyak akan membuat kandungan gluten pada roti semakin berkurang yang membuat pori-pori roti soft roll tampak semakin rapat (Pusuma et al, 2018). Setelah melalui uji tukey, 
sampel 285 berbeda nyata dengan sampel 903. Roti soft roll dengan substitusi tepung hanjeli yang semakin besar menghasilkan pori-pori roti yang lebih rapat seperti dapat dilihat pada Gambar 1.

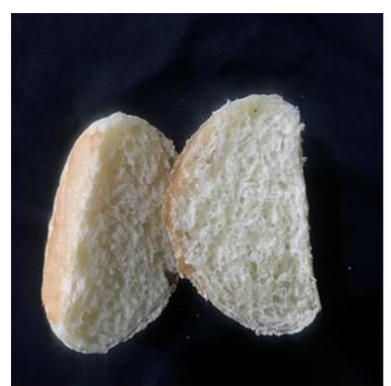

Kontrol

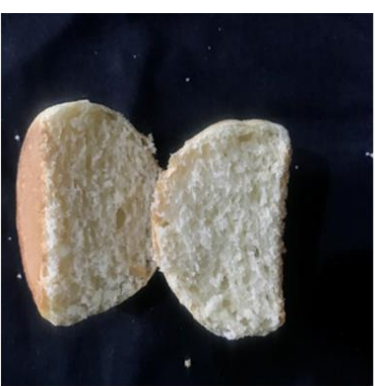

P1

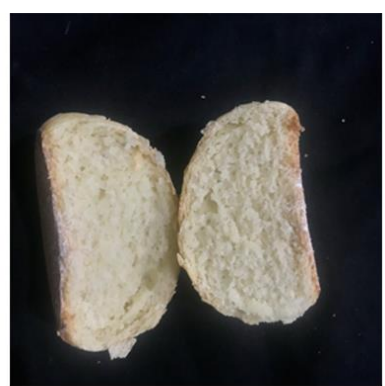

P2

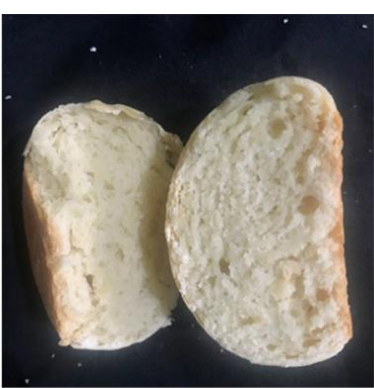

P3

Gambar 1. Penampang roti soft roll

Tabel 7. Penilaian Hasil Uji Daya Terima Aspek Warna Crumb

\begin{tabular}{lcccccc}
\hline \multirow{2}{*}{ Skala Penilaian } & \multicolumn{7}{c}{ Roti Soft Roll Substitusi Tepung Hanjeli } \\
\cline { 2 - 7 } & \multicolumn{7}{c}{$30 \%$} & \multicolumn{7}{c}{$20 \%$} & \multicolumn{1}{c}{$10 \%$} \\
\cline { 2 - 7 } & $\mathrm{n}$ & $\%$ & $\mathrm{n}$ & $\%$ & $\mathrm{n}$ & $\%$ \\
\hline Sangat Suka & 5 & 20 & 9 & 36 & 8 & 32 \\
Suka & 17 & 68 & 13 & 52 & 15 & 60 \\
Agak Suka & 2 & 8 & 2 & 8 & 2 & 8 \\
Tidak Suka & 1 & 4 & 1 & 4 & 0 & 0 \\
Sangat Tidak Suka & 0 & 0 & 0 & 0 & 0 & 0 \\
\hline Jumlah & 25 & 100 & 25 & 100 & 25 & 100 \\
\hline Mean & $4,04 \pm 0,68$ & \multicolumn{7}{c}{$4,20 \pm 0,76$} & & $4,24 \pm 0,60$ & \\
Modus & 4 & 4 & & 4 & \\
\hline
\end{tabular}

Rata-rata skor penilaian hasil uji daya terima aspek warna crumb pada roti soft roll substitusi tepung hanjeli menunjukkan bahwa, roti soft roll substitusi tepung hanjeli 30\% dengan skor 4,04; $20 \%$ dengan skor 4,20; dan 10\% dengan skor 4,24 termasuk ke dalam kategori suka. Setelah dilakukan uji Friedman nilai $\mathrm{x}$ hitung diperoleh sebesar 2,743 yang dapat diartikan tidak terdapat perbedaan terhadap aspek warna crumb pada sampel roti soft roll. Sampel roti soft roll yang dihasilkan memiliki warna crumb yang cerah.

Tabel 8. Penilaian Hasil Uji Daya Terima Aspek Aroma

\begin{tabular}{|c|c|c|c|c|c|c|}
\hline \multirow{3}{*}{ Skala Penilaian } & \multicolumn{6}{|c|}{ Roti Soft Roll Substitusi Tepung Hanjeli } \\
\hline & \multicolumn{2}{|c|}{$30 \%$} & \multicolumn{2}{|c|}{$20 \%$} & \multicolumn{2}{|c|}{$10 \%$} \\
\hline & $\mathrm{n}$ & $\%$ & $\mathrm{n}$ & $\%$ & $\mathrm{n}$ & $\%$ \\
\hline Sangat Suka & 2 & 8 & 6 & 24 & 4 & 16 \\
\hline Suka & 5 & 20 & 9 & 36 & 17 & 68 \\
\hline Agak Suka & 18 & 72 & 10 & 40 & 4 & 16 \\
\hline Tidak Suka & 0 & 0 & 0 & 0 & 0 & 0 \\
\hline Sangat Tidak Suka & 0 & 0 & 0 & 0 & 0 & 0 \\
\hline Jumlah & 25 & 100 & 25 & 100 & 25 & 100 \\
\hline Mean & $3,36^{b} \pm 0,64$ & & $3,84^{\mathrm{ac}} \pm 0,80$ & & $4,00^{a} \pm 0,58$ & \\
\hline Modus & 3 & & 3 & & 4 & \\
\hline
\end{tabular}

Keterangan : Angka-angka yang diikuti oleh huruf yang berbeda pada baris yang sama berbeda nyata pada taraf signifikansi 0,05 
Rata-rata skor penilaian hasil uji daya terima aspek aroma pada roti soft roll substitusi tepung hanjeli menunjukkan bahwa, roti soft roll substitusi tepung hanjeli 30\% dengan skor 3,36 termasuk ke dalam kategori agak suka. Sedangkan roti soft roll substitusi tepung hanjeli 20\% dengan skor 3,84 termasuk ke dalam kategori mendekati suka dan 10\% dengan skor 4,00 termasuk ke dalam kategori suka. Setelah dilakukan uji Friedman nilai $x$ hitung diperoleh sebesar 12,816 yang dapat diartikan terdapat perbedaan terhadap aspek aroma pada sampel roti soft roll. Penggunaan tepung hanjeli yang semakin tinggi akan mebuat aroma roti menghasilkan aroma khas hanjeli semakin kuat. Setelah melalui uji tukey, terdapat dua buah pasangan data yang berbeda nyata, yaitu sampel 285 berbeda nyata dengan sampel 903 dan sampel 389 berbeda nyata dengan sampel 903.

Tabel 9. Penilaian Hasil Uji Daya Terima Aspek Rasa Hanjeli

\begin{tabular}{|c|c|c|c|c|c|c|}
\hline \multirow{3}{*}{ Skala Penilaian } & \multicolumn{6}{|c|}{ Roti Soft Roll Substitusi Tepung Hanjeli } \\
\hline & \multicolumn{2}{|c|}{$30 \%$} & \multicolumn{2}{|c|}{$20 \%$} & \multicolumn{2}{|c|}{$10 \%$} \\
\hline & $n$ & $\%$ & $n$ & $\%$ & $\mathrm{n}$ & $\%$ \\
\hline Sangat Suka & 1 & 4 & 4 & 16 & 10 & 40 \\
\hline Suka & 7 & 28 & 12 & 48 & 7 & 28 \\
\hline Agak Suka & 16 & 64 & 8 & 32 & 7 & 28 \\
\hline Tidak Suka & 1 & 4 & 1 & 4 & 1 & 4 \\
\hline Sangat Tidak Suka & 0 & 0 & 0 & 0 & 0 & 0 \\
\hline Jumlah & 25 & 100 & 25 & 100 & 25 & 100 \\
\hline Mean & $3,32^{b} \pm 0,63$ & & $3,76^{a b} \pm 0,78$ & & $4,04^{a} \pm$ & \\
\hline Modus & 3 & & 4 & & 5 & \\
\hline
\end{tabular}

Rata-rata skor penilaian hasil uji daya terima aspek rasa hanjeli pada roti soft roll substitusi tepung hanjeli menunjukkan bahwa, roti soft roll substitusi tepung hanjeli 30\% dengan skor 3,32 termasuk ke dalam kategori agak suka. Sedangkan roti soft roll substitusi tepung hanjeli 20\% dengan skor 3,76 termasuk ke dalam kategori mendekati suka dan 10\% dengan skor 4,04 termasuk ke dalam kategori suka. Setelah dilakukan uji Friedman nilai x hitung diperoleh sebesar 14,800 yang dapat diartikan terdapat perbedaan terhadap aspek rasa hanjeli pada sampel roti soft roll. Penggunaan tepung hanjeli yang semakin banyak pada pembuatan roti soft roll membut roti yang dihasilkan memiliki cita rasa hanjeli yang semakin kuat. Setelah melalui uji tukey, sampel 285 berbeda nyata dengan sampel 903.

Rata-rata skor penilaian hasil uji daya terima aspek rasa manis pada roti soft roll substitusi tepung hanjeli menunjukkan bahwa, roti soft roll substitusi tepung hanjeli 30\% dengan skor 3,88 termasuk ke dalam kategori mendekati suka. Sedangkan roti soft roll substitusi tepung hanjeli $20 \%$ dan $10 \%$ memiliki skor 4,16 yang termasuk ke dalam kategori suka. Setelah dilakukan uji Friedman nilai $x$ hitung diperoleh sebesar 3,455 yang dapat diartikan tidak terdapat perbedaan terhadap aspek rasa manis pada sampel roti soft roll. Sampel roti soft roll substitusi yang dihasilkan tidak memiliki rasa manis berbeda yang signifikan. 
Tabel 10. Penilaian Hasil Uji Daya Terima Aspek Rasa Manis

\begin{tabular}{lcccccc} 
& \multicolumn{7}{c}{ Roti Soft Roll Substitusi Tepung Hanjeli } \\
\cline { 2 - 7 } \multicolumn{1}{c}{ Skala Penilaian } & \multicolumn{2}{c}{$30 \%$} & \multicolumn{2}{c}{$20 \%$} & \multicolumn{1}{c}{$10 \%$} \\
\cline { 2 - 7 } & $\mathrm{n}$ & $\%$ & $\mathrm{n}$ & $\%$ & $\mathrm{n}$ & $\%$ \\
\hline Sangat Suka & 1 & 4 & 6 & 24 & 7 & 28 \\
Suka & 20 & 80 & 17 & 68 & 15 & 60 \\
Agak Suka & 4 & 16 & 2 & 8 & 3 & 12 \\
Tidak Suka & 0 & 0 & 0 & 0 & 0 & 0 \\
Sangat Tidak Suka & 0 & 0 & 0 & 0 & 0 & 0 \\
\hline Jumlah & 25 & 100 & 25 & 100 & 25 & 100 \\
\hline Mean & $3,88 \pm 0,44$ & & $4,16 \pm 0,55$ & & $4,16 \pm 0,62$ & \\
Modus & 4 & 4 & 4 &
\end{tabular}

Tabel 11. Penilaian Hasil Uji Daya Terima Aspek Tekstur

\begin{tabular}{lcccccc}
\hline \multirow{2}{*}{ Skala Penilaian } & \multicolumn{7}{c}{ Roti Soft Roll Substitusi Tepung Hanjeli } \\
\cline { 2 - 7 } & \multicolumn{2}{c}{$30 \%$} & $\mathrm{n}$ & $20 \%$ & & $10 \%$ \\
\cline { 2 - 7 } & $\mathrm{n}$ & $\%$ & 5 & 20 & 7 & 28 \\
\hline Sangat Suka & 1 & 4 & 11 & 44 & 15 & 60 \\
Suka & 11 & 44 & 9 & 36 & 3 & 12 \\
Agak Suka & 13 & 52 & 0 & 0 & 0 & 0 \\
Tidak Suka & 0 & 0 & 0 & 0 & 0 & 0 \\
Sangat Tidak Suka & 0 & 0 & 25 & 100 & 25 & 100 \\
\hline Jumlah & 25 & 100 & $3,84^{\mathrm{ab}} \pm 0,75$ & & $4,16^{\mathrm{a}} \pm 0,62$ & \\
\hline Mean & $3,52^{\mathrm{b}} \pm 0,59$ & & 4 & 4 &
\end{tabular}

Keterangan : Angka-angka yang diikuti oleh huruf yang berbeda pada baris yang sama berbeda nyata pada taraf signifikansi 0,05

Rata-rata skor penilaian hasil uji daya terima aspek tekstur pada roti soft roll substitusi tepung hanjeli menunjukkan bahwa, roti soft roll substitusi tepung hanjeli 30\% dengan skor 3,52 dan 20\% dengan skor 3,84 termasuk ke dalam kategori mendekati suka. Sedangkan roti soft roll substitusi tepung hanjeli $10 \%$ dengan skor 4,16 termasuk ke dalam kategori suka. Setelah dilakukan uji Friedman nilai $\mathrm{x}$ hitung diperoleh sebesar 11,571 yang dapat diartikan terdapat perbedaan terhadap aspek tekstur pada sampel roti soft roll. Penggunaan tepung hanjeli yang semakin besar akan menghasilkan roti soft roll yang lebih kering. Hal ini disebabkan karena kandungan air pada tepung hanjeli yang hanya sebesar 7,9\% dibandingkan dengan tepung terigu yang $12 \%$ (Kurniasih, 2016). Kandungan air yang rendah pada tepung hanjeli akan membuat adonan roti yang dihasilkan agak sedikit lebih kering dan menghasilkan roti soft roll yang agak kering juga. Setelah melalui uji tukey, sampel 285 berbeda nyata dengan sampel 903 . 


\section{Analisis Sifat Fisik}

Setelah melakukan analisis fisik terhdap tepung hanjeli dan roti soft roll, berikut ini adalah pemaparannya.

Tabel 12. Hasil Analisis Fisik Tepung Hanjeli

\begin{tabular}{lccc} 
Teknik & $\begin{array}{c}\text { Densitas Kamba } \\
(\mathrm{g} / \mathrm{ml})\end{array}$ & $\begin{array}{c}\text { Densitas Pemadatan } \\
(\mathrm{g} / \mathrm{ml})\end{array}$ & $\begin{array}{c}\text { Daya Serap Air } \\
(\%)\end{array}$ \\
\hline Hasil & $0,54 \pm 1,15$ & $0,71 \pm 1,00$ & $56 \pm 0,08$
\end{tabular}

Densitas kamba merupakan perbandingan antara berat tepung dengan volume suatu wadah. Tepung dimasukan ke dalam wadah tanpa dipadatkan. Pada tabel 12 dapat diketahui nilai densitas kamba tepung hanjeli adalah $0,54 \mathrm{~g} / \mathrm{ml}$. Densitas Pemadatan merupakan perbandingan antara berat tepung dengan volume suatu wadah dengan adanya proses pemadatan tepung pada wadah. Nilai densitas pemadatan tepung hanjeli adalah $0,71 \mathrm{~g} / \mathrm{ml}$.

Daya serap air merupakan kemampuan tepung dalam menyerap air. Hasil perhitungan diperoleh dengan membagi jumlah air yang digunakan untuk membentuk adonan tepung hanjeli 25 gram hingga tidak lengket ditangan kemudian dikalikan dengan 100\%. Hasil penelitian menunjukkan nilai daya serap air tepung hanjeli sebesar $56 \%$.

Tabel 13. Hasil Analisa Fisik Roti Soft Roll

\begin{tabular}{lcccc}
\hline Perlakuan & Kontrol & P1 & P2 & P3 \\
\hline Volume Roti & $63,00^{\mathrm{a}} \pm 1,73$ & $47,33^{\mathrm{b}} \pm 1,53$ & $43,33^{\mathrm{c}} \pm 1,15$ & $33,67 \mathrm{~d} \pm 0,58$ \\
\hline Rasio Pengembangan (\%) & $29,2^{\mathrm{a}} \pm 2,52$ & $27,97^{\mathrm{a}} \pm 3,94$ & $24,46^{\mathrm{a}} \pm 1,68$ & $12,91^{\mathrm{b}} \pm 6,87$
\end{tabular}

Keterangan : Angka-angka yang diikuti oleh huruf yang berbeda pada baris yang sama berbeda nyata pada taraf signifikansi 0,05

Tabel 13 menunjukan hasil perhitungan volume roti dengan metode biji-bijian dan rasio pengembangan pada roti soft roll. Nilai volume roti diperoleh dengan mengurangkan berat biji-bijian yang menempati seluruh ruang pada suatu wadah dan berat biji-bijian ketika wadah tersebut berisikan roti. Semakin besar nilainya maka semakin besar volume pada roti. Rasio pengembangan roti dihitung dengan cara mengurangkan tinggi roti setelah dipanggang dengan tinggi roti sebelum proses proofing, kemudian dibagi dengan tinggi roti setelah dipangang dan dikalikan dengan seratus persen. Semakin besar persentase rasio pengembangan maka menujukkan semakin besar proses pengembangan pada adonan roti hingga roti matang dipanggang. Substitusi tepung hanjeli dalam pembuatan roti soft roll yang semakin besar persentasenya akan menghasilkan volume roti dan pengembangan yang semakin kecil. 


\section{KESIMPULAN}

Semakin banyak penggunaan tepung hanjeli pada pembuatan roti soft roll mengakibatkan volume roti yang tidak optimal, warna kulit roti yang semakin pucat, pori-pori roti yang semakin rapat, aroma dan rasa hanjeli yang semakin kuat, serta tekstur roti yang semakin kering. Roti soft roll substitusi tepung hanjeli yang paling banyak disukai oleh panelis pada aspek internal adalah roti soft roll substitusi tepung hanjeli dengan perlakuan tepung terigu $90 \%$ : tepung hanjeli $10 \%$ dan pada aspek eksternal adalah roti soft roll substitusi tepung hanjeli dengan perlakuan tepung terigu $80 \%$ dan tepung hanjeli $20 \%$. Secara umum roti soft roll dengan substitusi tepung hanjeli $10 \%$ lebih unggul, dengan jumlah tujuh aspek.

\section{DAFTAR PUSTAKA}

Asosiasi Produsen Tepung Terigu Indonesia. 2016. Indonesian Wheat Flour Industry Overview. aptindo.or.id/wpcontent/uploads2016/10/Overview-Oct-2016-pdf [01 Desember 2020].

Khalil. 1999. Pengaruh Kandungan Air dan Ukuran Partikel Terhadap Perubahan Perilaku Fisik Bahan Pangan Lokal. Media Peternakan 22(1): 1-11.

Koswara S. 2009. Teknologi Pengolahan Roti. Tekpan.unimus.ac.id/wp-content/uploads/2013/07/Teknologi-Rotidan-Praktek.pdf [10 September 2020].

Kurniasih R. 2016. Formulasi Daya Terima Kandungan Gizi dan Kapasitas Antioksidan Pasta Jali (Coix Lacrymajobi Linn) Dengan Penambahan Ekstrak Torbangun. Skripsi. Fakultas Ekologi Manusia, Institut Pertanian Bogor. Bogor

Kusumayanti H, Handayani NA, Santosa H. 2014. Swelling Power and Water Solubility of Cassava and Sweet Potatoes Floue. Procedia Environmental Sciences 23: 164-167. DOl: 10.1016/.jproenv.2015.01.025.

Kutschera M, Krasaekoopt W. 2012. The Use of Job's Tear (Coix Lacryma -jobi L.) Flour to Substitute Cake Flour in Butter Cake. Au J.T. 15(4): 233-238.

Litbang, 2013. Diversifikasi Pangan dan Transformasi Pembangunan Pertanian. 165-166. IAARD, Jakarta.

Muchtadi TR, Sugiyono, Ayustaningwarno F. 2010. Ilmu Pengetahuan Bahan Pangan. 236. Alfabeta, Bandung.

Mudjajanto ES, Yuliati LN. 2013. Bisnis Roti. 26-76. Penebar Swadaya, Jakarta.

Pusuma DA, Praptiningsih Y, Choiron M. 2018. Karakteristik Roti Tawar Kaya Serat Yang Disubstitusi Menggunakan Tepung Ampas Kelapa. Jurnal Agroteknologi 12(1): 29-42. DOI: 10.19184/j-agt.v12i1.7886.

Rahmah A, Hamzah F, Rahmayuni. 2017. Penggunaan Tepung Komposit Dari Terigu, Pati Sagu Dan Tepung Jagung Dalam Pembuatan Roti Tawar. Jom FAPERTA 4(1): 1-14. 
Sumaryanto. 2009. Diversifikasi Sebagai Salah Satu Pilar Ketahanan Pangan. Forum Penelitian Agro Ekonomi 27(2): 93-108. DOl: 10.21082/fae.v27n2.2009.93-108.

Supadi. 2009. Dampak Impor Kedelai Berkelanjutan Terhadap Ketahanan Pangan. Analisis Kebijakan Pertanian 7(1): 87-102. DOl: 10.21082/akp.v7n1.2009.87-102.

Surono DI, Nurali EJN, Moningka JSC. 2017. Kualitas Fisik dan Sensoris Roti Tawar Bebas Gluten Bebas Kasein Berbahan Dasar Tepung Komposit Pisang Goroho (Musa acuminate L). Cocos 1(1):1-12.

Syahputri DA, Wardani AK. 2015. Pengaruh Fermentasi Jali (Coix Lacryma jobi-L) Pada Proses Pembuatan Tepung Terhadap Karakteristik Fisik dan Kimia Cookies dan Roti Tawar. Jurnal Pangan dan Agroindustri. 3(3) 984-995.

US. Wheat Associates. 1983. Pedoman Pembuatan Roti dan Kue. Djambatan, Jakarta.

Wijayanti YR. 2007. Substitusi Tepung Gandum (Triticum aestivum) Dengan Tepung Garut (Maranta arundinaceae L) Pada Pembuatan Roti Tawar. Skripsi. Fakultas Teknologi Pertanian, Universitas Gadjah Mada. Yogyakarta 